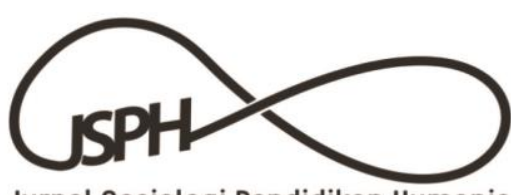

P-ISSN : 2502-7875 E-ISSN : 2527-5879

\title{
Merumuskan Ulang Konsep Moralitas: Sumbangan Pemikir Feminis
}

Paulus Bagus Sugiyono

Departemen Sosiologi Universitas Indonesia

Email : pbagussugiyono@gmail.com

\begin{abstract}
Abstrak
Tujuan artikel ini adalah untuk merumuskan ulang konsep mengenai moralitas, terutama ketika mendapatkan sumbangsih pemikiran dari para pemikir feminis. Metode yang digunakan dalam penelitian ini adalah kajian literatur dalam pendekatan kualitatif. Moral, dalam perjalanan panjang sejarah pemikiran barat, identik dengan pemikiran Immanuel Kant dalam sifatnya yang berlaku universal. Untuk mengakses universalitas moral, manusia diandaikan memiliki nalar atau rasionalitas yang cukup. Dengan demikian, sebagai manusia yang otonom secara moral, tidak ada alasan baginya untuk tidak mengikuti prinsip-prinsip moral. Penggunaan nalar tidak memberikan ruang bagi hal-hal yang sifatnya kontingen, seperti perasaan, sensitivitas, dan kecenderungan. Hasil penelitian ini menunjukkan bahwa apa yang disingkirkan oleh etika Kantian tadi diangkat oleh para pemikir feminis. Mereka memberikan sumbangsih pemikirannya tersendiri dalam membangun konsep moralitas. Selain itu, penelitian ini juga menunjukkan bahwa etika kepedulian adalah muara dari pemikiran mengenai moralitas dari para pemikir feminis. Meski demikian, etika kepedulian tidak hadir sebagai substitusi atau pengganti dari etika Kantian, melainkan sebagai komplementer yang menjadikan cakrawala moralitas semakin utuh. Bak dua sisi sepayang sayap, kedua pendekatan moralitas tadi saling menyeimbangkan pemaknaan mengenai apa itu moralitas, terutama untuk menelaah fenomena-fenomena secara sosiologis dalam masyarakat.
\end{abstract}

Kata kunci : rasionalitas, perasaan, pemikir feminis, etika Kantian, etika kepedulian

\section{Reconceptualization Morality: The Feminisme Contributions}

\begin{abstract}
The aim of this article is to re-conceptualize the meaning of morality according to the perspective of feminists. This article employed the method of literature review within the qualitative approach. Morality, in the history of western thought, is often related with the concept offered by Immanuel Kant. Human being is perceived to have a sufficient rationality to access the universal morality. Therefore, there is no reason for not following the principles of morality. The use of rationality definitely denies all of the contingent things, such as feeling, sensitivity, and inclination. The result of this study shows that the feminists tried to reflect on these contingent things, so that they could re-conceptualize the meaning of morality. They did believe that these contingent things have given such an influential meaning for the concept of morality. Besides, this study also points out that the concept of care ethics is thus a fruit of the feminists' thought. Even though, care ethics would not definitely substitute Kantian ethics, but rather complement it, so that the paradigm of the morality can be seen broader from several perspectives. This entwined paradigm, between Kantian and care ethics, is then can be employed to analyze various social phenomena that occur in our society.
\end{abstract}

Keywords : rationality, feeling, feminists, Kantian ethics, care ethics 


\section{PENDAHULUAN}

Hidup yang berguna dan bermanfaat adalah hidup yang selalu mengarah kepada kebaikan dan menjauhkan diri dari segala macam keburukan (Apressyan, 2020). Pedoman umum inilah yang menjadi kunci dalam bagaimana manusia menentukan dan mengambil keputusan atas setiap perilaku dalam hidupnya. James Rachels menyebut pedoman ini sebagai konsepsi minimal ketika seseorang berbicara mengenai moralitas (Rachels sebagaimana diterjemahkan oleh Sudiarja, 2004: 40). Dengan kata lain, secara umum, kita tentu dapat mengatakan bahwa konsep moralitas dapat dihubungkan erat dengan penentuan sikap baik dan buruk manusia dalam kehidupannya seharihari (Mahmud, 2016; Appresyan, 2020; Koh dan Reamer, 2020). Selanjutnya, Held (1998: 93) mengungkapkan bahwa dalam sejarah filsafat dan etika, konsep moralitas selalu erat dikaitkan dengan akses universal yang kompetensinya dilakukan oleh nalar atau rasionalitas manusia. Artinya, mereka yang memiliki nalar baik, sudah sepantasnya melakukan hal-hal yang baik pula di dalam hidupnya, tanpa terkecuali.

Hal tersebut, yang menurut Held (1998), menjadi sebuah pengandaian mula dan mendasar. Argumentasi demikian berdiri kokoh dan kuat, hingga akhirnya upaya-upaya rekonstruksi pemikiran hadir dari para pemikir feminis. Seperti yang telah dijelaskan tadi, akses terhadap moralitas telah sekian lama ditentukan oleh bagaimana nalar bekerja. Penggunaan nalar dikaitkan dengan mentalitas berpikir maskulin, yang seringkali diasosiasikan dengan mentalitas berpikir laki-laki. Berarti mentalitas berpikir perempuan sering dianggap tidak mampu mengakses moralitas, karena ketidakberdayaan nalar yang dimilikinya. Mentalitas berpikir perempuan lebih mencerminkan bagaimana rasa-perasaan mengambil kendali (Held, 1998: 99-100). Sementara studi yang dilakukan Jena (2014) menemukan bahwa mentalitas berpikir perempuan yang diwarnai dengan kuat oleh rasa-perasaan tercermin dalam etika kepedulian. Secara khusus, studi yang dilakukan Jena (2014) menyatakan bahwa representasi etika kepedulian ini terwujud nyata dalam tindakan welas asih.

Dengan pendekatan etika kepedulian, tindakan welas asih, dapat dikategorikan sebagai tindakan moral. Lebih lanjut, Jena (2014) mengatakan bahwa tindakan welas asih ini begitu khas, sehingga dapat dibedakan dari sikap altruistik manusia. Tindakan welas asih lebih dekat dengan konsep dan tindakan simpati. Seperti pendekatan yang dilakukan Jena (2014), tulisan ini bermaksud memaparkan suatu pemahaman mengenai etika kepedulian dalam konseptualisasi moralitas.

Meski demikian, berbeda dengan studi yang dilakukan oleh Jena (2014) yang lebih menekankan pada representasi etika kepedulian, studi yang dipaparkan dalam tulisan ini lebih ingin melacak jejak kemunculan etika kepedulian dan sumbangsihnya dalam konseptualisasi moralitas. Alih-alih mencoba mendekati pemahaman etika kepedulian dari "bawah" atau praksis nyatanya sebagaimana yang dilakukan Jena (2014), studi ini lebih ingin mendekati etika kepedulian dari "atas" atau pada kemunculan dalam proses konseptualisasi.

Tujuan tulisan ini berupaya menjawab pertanyaan dasar mengenai bagaimana sejarah konsep moralitas berkembang dan berjumpa dengan kritik para pemikir feminis. Keterlibatan para pemikir feminis membuktikan bahwa mereka tidak diam saja. Sebagai cendekiawan yang berhak dan wajib mengaktualisasikan kompetensi dirinya, mereka terlibat untuk menyuarakan apa yang menjadi kegelisahan mereka. Keterlibatan teoretis ini tidak hanya berhenti pada ranah diskursus, tetapi pergi melampauinya dan masuk ke dalam praksis hidup harian.

\section{METODE PENELITIAN}

Penelitian ini menggunakan metode kajian literatur dalam pendekatan kualitatif. Pertama, dikaji sumber-sumber bacaan yang berisi konsep yang berbicara mengenai moralitas dalam pendekatan Kantian. Pendekatan ini merupakan pendekatan paling umum yang sering digunakan ketika kita berbicara tentang 
moralitas. Setelah itu, konsep-konsep mengenai moralitas akan dielaborasi dari sudut pandang para pemikir feminis. Secara khusus, digunakan tulisan dari Marilyn Friedman (2000) yang berjudul "Feminism in Ethics: Conception of Autonomy". Dari sanalah kemudian ditarik simpul-simpul penting mengenai sumbangsih khas moralitas dari para pemikir feminis ini. Kesimpulan mengenai konsep-konsep moralitas dirajut dengan mempertemukan kedua konsep pemikiran. Dari kedua konsep ini, penulis menarik sintesis yang menawarkan kebaruan untuk menjawab pertanyaan apakah yang dimaksud dengan moralitas itu. Dalam bagian pembahasan akhir, diberikan pula beberapa catatan kritis mengenai posisi sumbangsih pemikiran feminis tersebut dalam kebaruan konseptualisasi moralitas tadi.

\section{HASIL DAN PEMBAHASAN}

\section{Menelusuri Makna Moralitas}

Justinus Sudarminta, dalam bukunya yang berjudul Etika Umum (2010: 3), mengatakan bahwa kata "moral" berasal dari bahasa Latin "mos" atau "moris" yang berarti "adat kebiasaan". Arti kata ini sama dengan kata "etika" dalam bahasa Yunani. Akan tetapi, Sudarminta melanjutkan, kedua istilah ini pada perkembangannya dibedakan satu sama lain. Istilah "etika" digunakan untuk menyebut ilmu dan prinsip dasar mengenai penilaian baik dan buruknya perilaku manusia. Maka, tidak jarang kita kemudian menjumpai terminologi ini sebagai sebuah kata yang merujuk pada ilmu tertentu yang kita dapat di bangku perkuliahan atau dalam buku-buku tertentu, misalnya etika bisnis, etika komunikasi, etika kedokteran, dan lain sebagainya. Di lain pihak, istilah "moral" lebih mengacu kepada aturan dan norma yang lebih konkret bagi penilaian baik dan buruknya perilaku manusia. Tatarannya berada pada ruang lingkup yang lebih praktis dibandingkan dengan terminologi "etika" yang masih berada pada tataran abstraksi.

Secara lebih lanjut, Sudarminta (2010: 1516) mengatakan bahwa ada empat kekhasan moral yang menjadikannya ciri sebagai sebuah norma sosial yang berlaku di dalam masyarakat.
Pertama, norma moral merupakan sesuatu yang fundamental atau dasariah. Norma ini merujuk manusia langsung sebagai manusia atau manusia per se tanpa ada "embel-embel" yang dilekatkan (embedded) padanya. Ia menghujam ke dalam inti pribadi seseorang sebagai being qua being. Implikasi dari ciri ini tentu adalah kesetaraan semua manusia yang ada di dunia. Kedua, norma moral menegaskan kewajiban dasar manusia. Rupa bentuknya dapat terejawantahkan dalam perintah atau larangan (Apressyan, 2020). Meskipun bukan kekhasan yang mutlak (sebab norma hukum dan norma sopan santun kerap juga dirumuskan menggunakan perintah dan larangan), norma moral dalam bentuk perintah dan larangan menjadi bentuk paling konkret dan paling sering dijumpai sebagai pedoman hidup manusia untuk melakukan hal yang baik dalam hidupnya.

Ketiga, norma moral berlaku universal. Keberlakuan universal berarti keberlakuannya yang umum. Tidak ada manusia yang dapat lepas dari perintah dan larangan moral ini. Dihadapan norma moral, semua manusia berkedudukan sama. Mengutip filsuf Immanuel Kant, Sudarminta (2010) mengatakan bahwa moralitas berlaku universal, karena manusia adalah makhluk yang rasional. Dengan rasionalitasnya, siapapun manusia dapat mengakses moralitas. Untuk itu, ia tidak dapat menghindar dari "kewajiban" yang ditujukan kepadanya (Soloviev, 2018). Keempat, norma moral mengarahkan perilaku manusia untuk menuju kepenuhan hidup sebagai seorang manusia, atau setidaknya kepedulian pada orang lain. Sebagaimana ciri perintah dan larangan, ciri ini tidak berlaku hanya bagi norma moral (Sudarminta, 2010: 16-17). Akan tetapi, setidaknya ciri ini ingin mengatakan bahwa kepenuhan dan keutuhan manusia harus menjadi tujuan setiap tindak dan perilakunya

\section{Otonomi Moral: Perjumpaan antara Kant dan Pemikir Feminis}

Berdasarkan uraian sebelumnya, salah satu ciri norma moral yang dapat dilihat dan diperdalam lebih lanjut adalah cirinya yang universal. Dalam ciri ini, moralitas mengikat semua orang tanpa terkecuali. Kant menyebut 
bahwa manusia memiliki akses ke dalam universalitas moralitas ini melalui rasionalitas atau nalarnya (Asdi, 1995; Dahlan, 2009; Gusmian, 2014; Soloviev, 2018). Dengan menggunakan kapasitas rasionalitas atau nalar, manusia memiliki sebuah otonomi tersendiri. Para pelaku moral otonom, dengan demikian, tidak serta-merta hanya mengikuti tradisi atau ajaran-ajaran moral yang sudah berlaku begitu saja (taken for granted) atau turun-temurun dalam masyarakat, tetapi sungguh mampu mengakses moralitas melalui nalarnya sendiri.

Apa yang menjadi hukum atau maxim moral bagi Kant dengan demikian adalah hanya bila memiliki bentuk universal dan niscaya. Hukum yang universal ini hanya dapat dipahami melalui nalar. Segala bentuk perasaan, hasrat, dan kecenderungan tidak mampu untuk mengakses hukum yang universal ini, karena mereka bersifat kontingen dan partikular. Rasionalitas baru dapat dikatakan imparsial ketika ia tidak lagi dipengaruhi oleh hal-hal yang kontingen dan partikular ini (Friedman, 2000: 212). Terhadap pendekatan Kantian yang demikian, para pemikir feminis menolaknya. Mereka berdiri tegak untuk mendebat dan berani mengutarakan apa yang menjadi keresahan dan pendapat mereka sendiri.

Frase kata "pemikir feminis" di sini mengacu kepada gerakan-gerakan yang dilakukan oleh lebih dari satu orang yang memiliki concern pada pemikiran feminis. Marilyn Friedman menyebut beberapa dari antara mereka, seperti Annette Baier, Seyla Benhabib, Lawrence Blum, Claudia Card, Owen Flanagan, Jean Grimshaw, Virginia Held, Kathryn Jackson, Allison Jaggar, Nel Noddings, Bill Puka, Sara Ruddick, Joan C. Tronto, Margaret Walker, dan dirinya sendiri (Friedman, 2000: 209). Para pemikir feminis menolak pendekatan Kantian yang mengabaikan atau setidaknya mengesampingkan pentingnya peran perasaan, relasi personal yang dekat, dan relasi sosial manusia. Marilyn Friedman melihat bahwa otonomi moral Kant cenderung menolak adanya kedekatan personal antar manusia (close personal relationship) dan sikap perhatian (care) satu sama lain.

Padahal, Friedman mengatakan bahwa apabila kita mengabaikan peran sensitivitas perasaan dan sikap terhadap orang lain, maka akan menjadi sulit bagi kita untuk mengembangkan perhatian mendalam akan situasi moral. Dalam sebuah situasi moral, reaksi rasa-perasaan amatlah penting. Friedman mempertanyakan, bagaimana kita dapat berbela rasa terhadap orang lain yang sedang berada dalam situasi moral tertentu apabila kita tidak menggunakan perasaan untuk mengembangkan perhatian mendalam terhadap orang lain? (Friedman, 2000: 212-213). Kritik lain disampaikan Friedman terkait dengan pembentukan pemahaman moralitas. Friedman melihat bahwa pemahaman moral (moral understanding) sebetulnya merupakan sebuah usaha yang terbentuk dalam komunitas dimana manusia berada dan berkembang. Di dalam komunitas tersebut terjadi perjumpaan antarmanusia yang saling berkomunikasi satu sama lain. Manusia tidak bisa dikatakan "tahu begitu saja" mengenai moral yang berlaku, melainkan mendapatkan pengajaran, didikan, maupun sosialisasi dari manusia-manusia lain yang ada di sekitarnya.

Dalam hal inilah, Friedman mengatakan, sisi sosialitas bermain. Manusia tidak pernah terkungkung dan dapat dilepaskan dari pengaruh manusia lainnya. Dengan demikian, dapat dikatakan bahwa alih-alih merupakan sesuatu yang terisolasi sebagaimana diajukan Kant, Friedman berpendapat bahwa nalar moral sesungguhnya berdasar pada kehidupan sosial. Penalaran seorang manusia terbentuk dari pengalaman-pengalamannya dalam kehidupan sosial tersebut (Friedman, 2000: 213). Contoh sederhana tentu dapat diberikan untuk menggambarkan kritik Friedman di atas. Sebagai contoh, seorang anak mengetahui dan memahami bahwa tindakan mencuri mainan di toko adalah tindakan yang buruk. Pengetahuan dan pemahaman anak ini tentu tidak terjadi begitu saja, melainkan melibatkan orang lain dalam proses penanamannya. Ada banyak orang 
yang dapat diandaikan terlibat dalam proses ini, misalnya orangtua di rumah atau para guru di sekolah. Dengan demikian, pengetahuan dan pemahaman anak terhadap tindakan mencuri yang dikategorikan buruk tidak dapat dilepaskan dari pengaruh orangtua maupun guru yang mendidik mereka.

Apa yang telah diajukan oleh Marilyn Friedman dan menjadi keberatannya atas argumentasi Kant mengenai otonomi moral sebenarnya bukanlah tanpa sebab. Gerakan pemikir feminis yang mulai melaju kencang di tahun 1960-an, salah satu penyebabnya dipicu oleh kritik dalam bidang psikologi moral yang diberikan oleh Carol Gilligan, seseorang yang terkenal dengan teori mengenai perkembangan moral perempuan. Carol Gilligan memberikan kritiknya untuk mendebat hasil penelitian yang dilakukan oleh Lawrence Kohlberg. Lawrence Kohlberg sendiri adalah seorang psikolog dan pendidik yang terkenal dengan teorinya mengenai perkembangan moral (theory of moral development).

Pada dasarnya, Kohlberg sebenarnya tidak mengajukan sebuah prinsip moral mengenai perilaku yang baik dan buruk dalam hidup. Penelitian Kohlberg lebih bertujuan untuk melihat sejauh mana kompetensi memberikan penilaian-penilaian moral dalam situasi konkret terjadi. Mengenai penelitian Kohlberg tersebut, Magnis-Suseno (2000: 115) menjabarkan dan memberi keterangannya demikian,

"Para responden diminta merefleksikan suatu
kasus dilematis, di mana yang paling terkenal
adalah dilema Heinz: Isteri Heinz sakit kanker
yang tidak dapat disembuhkan, tinggal paling
banyak enam bulan, perasaan nyeri tak
tertahan dan tidak ada obat yang berhasil
meredamnya. Ia meminta dokter untuk
memberikan dosis obat mematikan.
Pertanyaannya: Apakah dokter seharusnya
memenuhi permintaan itu? Berikan alasan atas
jawabanmu!" Magnis Suseno (2000: 155-156) mencatat, berdasarkan pertanyaan dilematis tersebut, Kohlberg secara khusus bukan memperhatikan jawaban yang diberikan, melainkan alasan-alasan yang diajukan untuk melakukan pembenaran atas pilihan jawabannya (justification). Respondennya adalah anak-anak. Atas pertimbangan apa anak-anak tersebut memberikan jawaban "ya" atau "tidak" pada sang dokter? Berdasarkan pertimbangan yang diberikan oleh anak-anak tersebut, Kohlberg menemukan adanya pola kognitif dalam memberikan pertimbangan moral.

Kohlberg lantas merumuskan bahwa ada tiga tahap dan enam perkembangan kesadaran moral. Tahap pertama adalah tingkat prakonvensional, dimana anak menangkap yang baik dan buruk sejauh dimengerti dari akibat fisik yang dirasakan. Tahap ini terdiri dari tahap orientasi hukuman dan ketaatan dan tahap orientasi perhitungan untung-rugi. Tahap kedua adalah tingkat konvensional dimana anak mulai mengidentifikasikan dirinya sebagai bagian suatu kelompok, entah itu keluarga, pertemanan, atau masyarakat luas.

Perbuatan baik dan buruk dalam ranah ini terkait erat dengan penerimaan di dalam kelompok yang diikutinya. Tahap ini terdiri dari tahap orientasi pada kelompok akrab dan tahap orientasi hukum dan tatanan. Tahap ketiga adalah tingkat pasca-konvensional di mana anak mulai melampaui kelompoknya. Nilai dan prinsip bersifat benar pada dirinya sendiri. Tahap ini terdiri dari tahap orientasi perjanjian sosial dan keadilan dan tahap orientasi pada prinsip-prinsip moral dan suara hati (Sudarminta, 2010: 79-82). Menurut Kohlberg, melalui tahap-tahap perkembangan moral sebagaimana telah dijelaskan sebelumnya, sebenarnya dalam titik tertentu ingin menekankan bahwa suatu tindakan atau perilaku bersifat moral apabila mengikuti suatu tolok ukur formal tertentu (the moral point of view). Dengan kata lain, sangat terlihat bahwa Kohlberg cenderung ingin menggarisbawahi peran kognisi dalam diri manusia.

Hal ini tidak mengherankan mengingat penelitian Kohlberg ini banyak dipengaruhi oleh etika normatif Kantian (Sudarminta, 2010: 82). Sebagai contoh, dalam tahap pertama, anak melakukan suatu tindakan berdasarkan rasa nikmat atau sakit yang diterimanya. Pada tahap kedua, ia mulai mengidentifikasikan tindakan mana yang dapat diterima oleh kelompoknya. 
Pada tahap yang terakhir, ia menemukan nilai yang benar pada dirinya sendiri. Semakin lama dari tahap ke tahap, terbentuk sebuah pola kognisi untuk dapat memahami dengan nalar apa yang disebut dengan baik atau buruk yang inheren di dalam dirinya sendiri.

Gilligan dalam bukunya: In a Different Voice: Psychological Theory and Women's Development, mengajukan keberatannya atas pendapat Kohlberg. Kohlberg, di dalam teori perkembangan moral, mengatakan bahwa lakilaki berada dalam tahap yang lebih tinggi dibandingkan dengan perempuan dengan cara pikir yang dimilikinya. Cara pikir lelaki yang dimaksud adalah cara pikir yang menekankan prinsip dan rasionalitas yang ketat. Cara pikir ini tidak memberi ruang pada perasaan, kepedulian, dan intimitas dengan orang lain, sebagaimana merupakan cara pikir yang khas atau diasosiasikan dengan perempuan (Rachels sebagaimana diterjemahkan oleh Sudiarja, 2004: 291). Konsep moral selama ini didominasi oleh cara pikir laki-laki yang menekankan nalar. Gilligan mengatakan bahwa cara pikir perempuan tidaklah lebih rendah daripada cara pikir laki-laki.

Gilligan mengatakan bahwa yang selama ini dianggap sebagai kelemahan cara pikir perempuan sebenarnya merupakan kekuatan cara pikir perempuan yang paling mendasar. Persis di sanalah kekuatan mereka berada (Rachels sebagaimana diterjemahkan oleh Sudiarja, 2004: 292). Ada sumbangsih tertentu yang diberikan oleh perempuan pada bagaimana manusia mengakses moralitas.

\section{Sumbangsih Pemikir Feminis bagi Moralitas}

Sampai tahap ini, penulis melihat bahwa apa yang telah digaungkan dan didengungkan oleh para pemikir feminis adalah sebuah upaya untuk merumuskan ulang konsep moralitas sebagaimana telah dipahami hingga saat ini, yang begitu kental bernada Kantian. Manusia begitu mengagungkan rasionalitas atau nalarnya untuk mengakses moralitas dan menyingkirkan begitu saja apa yang disebut perasaan dan sensitivitas pengalaman sebagaimana ada atau diasosiasikan dengan cara berpikir perempuan. Penulis beranggapan bahwa para pemikir feminis memiliki sumbangsihnya tersendiri yang khas bagi pemahaman yang lebih luas mengenai apa itu moralitas.

Apa yang diperjuangkan oleh pemikir feminis itu kemudian banyak dikenal dengan sebutan etika kepedulian (care ethics). James Rachels, sebagaimana diterjemahkan oleh Sudiarja, mengutip apa yang disampaikan oleh Annette Baier demikian, "Kepedulian adalah kata kunci yang baru..." (Rachels sebagaimana diterjemahkan oleh Sudiarja, 2004: 297). Kata kunci ini berarti bahwa saya sebagai manusia memiliki keterkaitan dengan orang lain. Ada sebuah ikatan yang menghubungkan saya sebagai pribadi dan liyan sebagai pihak lain yang tidak dapat dengan mudah dilepaskan begitu saja. Saya tidak dapat mengabaikan orang lain ketika saya hidup bersama-sama dengannya di dalam dunia ini. Persis disinilah letak salah satu esensi dari identitas manusia sebagai makhluk sosial.

Penulis melihat bahwa kepedulian terhadap orang lain sebagai sebuah etika tentu tidak dapat lepas dari pola pikir yang identik atau diasosiasikan dengan perempuan, sebagaimana telah penulis jelaskan di dalam bagian sebelumnya. Perasaan, sensitivitas pengalaman, dan keterhubungan dengan orang lain menjadi fondasi dasar yang kuat membangun etika kepedulian (Held, 2010; Engster, 2019; Miller, 2020). Hal inilah yang menjadi sumbangsih para pemikir feminis dalam merumuskan ulang konsep moralitas.

Keketatan atau rigoritas moral sebagaimana kentalnya peran rasionalitas atau nalar dicairkan dengan perasaan yang sensitif dalam relasi dengan orang lain sebagai sebuah bentuk kepedulian (Jena, 2014). James Rachels menyebutkan contoh yang bagus terkait bagaimana etika kepedulian memberikan sumbangsihnya ini. Manusia jelas tidak dapat melepaskan relasi-relasi yang membentuk kepribadiannya yang utuh. Sebagai contohnya, orang tua tidak mungkin mendidik anaknya hanya karena alasan "kewajiban". Ada alasan 
yang lebih mendasar daripada "kewajiban", yakni cinta yang mendalam akan anaknya. Ia menginginkan agar anaknya dapat tumbuh dan berkembang dengan baik. Cinta inilah yang merupakan suatu bentuk nyata dari etika kepedulian (Rachels sebagaimana diterjemahkan oleh Sudiarja, 2004: 297-298). Paling konkret dan sederhana, seorang manusia tidak dapat lepas dari relasi dengan anggota-anggota keluarganya.

\section{Catatan Kritis}

Penulis telah menjabarkan bagaimana usaha pemikir feminis merumuskan ulang konsep moralitas dalam sebuah kompleksitas perjalanan panjang sejarah pemikiran barat. Unsur kental nalar dalam akses moralitas dicairkan dengan dimensi perasaan yang ada dalam etika kepedulian. Berakar dari pengalaman dan penemuan jati dirinya, para pemikir feminis melibatkan diri mereka dalam kontestasi, bukan hanya pemikiran, tetapi lebihlebih praktik moralitas. Dalam bagian catatan kritis ini, penulis ingin menyampaikan beberapa catatan pribadi terkait dengan sumbangsih pemikir feminis dalam moralitas.

Pertama, para pemikir feminis telah membuka cakrawala pemahaman filsosofis eksistensi manusia dalam rangka moralitas. Hal ini berkaitan dengan identitas mendasar yang menjadi ciri khas manusia. Manusia sejatinya tidak hanya terdiri dari rasionalitas atau nalar saja. Ada dimensi rasa yang mungkin selama ini cenderung dilupakan atau dikesampingkan, mengingat upaya para pemikir selama ini yang berupaya memurnikan dirinya dari hal-hal yang bersifat kontingen. Padahal, tidak semua pengalaman manusia melulu dapat ditelaah secara moral rasional. Blaise Pascal mengatakan bahwa tidak semua hal dapat dipahami dengan nalar atau rasionalitas saja. Rasa memiliki jalannya sendiri untuk membongkar dan menelusuri apa yang tidak dapat dipahami oleh nalar. Dengan kata lain, keseimbangan menjadi kata kunci yang merajut relasi antara rasionalitas atau nalar dan perasaan atau hal-hal kontingen serupa lainnya. Hanya dengan keseimbangan inilah pengalaman manusia dapat ditelaah secara lebih komprehensif dan mendalam.
Kedua, apa yang diperjuangkan oleh para feminis sebagai etika kepedulian, meski demikian, menurut penulis bukanlah sebuah etika pengganti atau substitusi. Dalam hal ini, etika kepedulian tetap tidak dapat menggantikan etika Kantian. Dalam praksis moralitas, Kant memberikan sumbangan yang sangat berharga terkait unsur universalitas dan objektivitas. Hal ini tidak dapat diabaikan atau dihapuskan begitu saja. Semua manusia tidak dapat lepas dari moralitas. Semua manusia yang memiliki nalar atau rasionalitas dapat mengakses moralitas tanpa terkecuali. Untuk itu, tindakannya terikat oleh moralitas. Salah satu konsep turunan dari hal ini yang seringkali kita dengar adalah prinsip golden rule yang kurang lebih meminta seseorang untuk memperlakukan orang lain seperti ia memperlakukan dirinya sendiri. Atau, dalam bentuk negatif, dapat pula dikatakan untuk tidak memperlakukan seseorang dengan perilaku tertentu bila ia sendiri tidak ingin diperlakukan dengan cara demikian.

Menurut penulis, posisi etika kepedulian persis hadir untuk tidak menggantikan etika Kantian. Etika kepedulian muncul sebagai sebuah pelengkap atau komplementer penilaian moralitas. Dengan demikian, penilaian moral tidak melulu bersifat rigor dan juga sekaligus pada saat yang sama lepas dari rigoritasnya. Penilaian moral menjadi lebih seimbang dan luas mengingat beragam perspektif yang diterapkan kepadanya.

Ketiga, catatan kritis tentu perlu diberikan pula kepada pemikir feminis secara umum. Kata "feminis" tidak berarti bahwa semua pemikir perempuan setuju dan mendukung etika kepedulian. Di antara para perempuan sendiri tentu terdapat keberagaman posisi dan pengalaman. Hal ini menjadi mafhum, mengingat setiap perempuan hidup dan berasal dari konteks kehidupan yang beranekaragam. Keberagaman inilah yang tentu memunculkan keberagaman pemikiran sebagai pemikir perempuan. Etika kepedulian harus dilihat sebagai kemajuan substansial dalam kerangka acuan etika filosofis kontemporer karena menantang hegemoni etika keadilan (ethics of right)." (Magnis-Suseno, 2002: 27).Selanjutnya, 
Etika kepedulian bukan etika yang dimiliki khas perempuan, melainkan komponen hakiki setiap etika yang memadai atas individu.

Keempat, apabila hendak diperluas cakrawala pemikirannya, penulis menemukan bahwa apa yang ingin diperjuangkan oleh etika kepedulian kurang lebih sejalan dengan apa yang dimaksud dengan konsep etika dalam pemikiran Emmanuel Levinas, seorang pemikir dari Perancis. Bagi Levinas, yang etis adalah pemberian diri bagi orang lain atau liyan. Keberadaan liyan meminta dari diriku sebuah bentuk pertanggungjawaban terhadapnya. Aku tidak dapat melepaskan tanggungjawabku begitu saja. Demikian kurang lebih etika Levinas berbicara. Etika Levinas sama sekali tidak berbicara mengenai diskursus atau konsep, tetapi lebih kepada tataran praktik pemberian diri bagi orang lain di mana posisi orang lain berada di atasku sebagai subyek (relasi asimetris). Kata-kata kunci yang mengaitkan etika kepedulian dan Levinas adalah kepedulian dan pemberian diri.

\section{PENUTUP}

Di dunia yang semakin berkembang ini, dimana situasi semakin kompleks, etika kepedulian sangatlah berguna untuk menjadi pelengkap dari etika Kantian. Di satu sisi, disadari bahwa unsur rigoritas dalam menilai situasi moral perlu ditekankan. Sisi imparsialitas dan objektivitas adalah sesuatu yang dibutuhkan dalam masyarakat yang menjunjung tinggi keadilan. Akan tetapi, kekompleksan atau heterogenitas situasi ada kalanya tidak memungkinkan tekanan pada rigoritas moral saja. Ada situasi tertentu (case by case) yang tidak bisa dilihat secara umum, melainkan sungguh harus ditelaah dan dicermati betul setiap aspek yang berpengaruh. Saat itulah, etika kepedulian mengambil dan memainkan perannya untuk melengkapi etika Kantian. Etika kepedulian melihat dan mengangkat apa yang diabaikan oleh etika Kantian, yakni sisi kontingensi manusia. Dengan menyeimbangkan kedua etika yang saling melengkapi ini, aspek moralitas tampak akan menjadi lebih humanis.
Manusia dilihat dari kedua sisi yang membentuk dirinya, yakni nalar dan rasa. Persis di sinilah letak sumbangsih dan keterlibatan para pemikir feminis sebagai cendekiawan dalam ranah perkembangan pemikiran mengenai konsep moralitas.

\section{DAFTAR RUJUKAN}

Apressyan, Ruben G. (2020). "Toward a core understanding of morality." Dalam Russian Studies in Philosophy. Vol.58, No.2, 93-108.

Asdi, Endang Daruni. (1995). "Imperatif kategoris dalam filsafat moral Immanuel Kant." Dalam Jurnal Filsafat. No.23 November 1995, 9-19.

Beauchamp, Tom. (1982). Philosophical Ethics: An Introduction to Moral Philosophy. New York: McGraw-Hill Book Company.

Dahlan, Moh. (2009). "Pemikiran filsafat moral Immanuel Kant." Dalam Jurnal Ilmu Ushuluddin. Vol. 8 No.1, Januari 2009, 37-48.

Engster, Daniel. (2019). "Care ethics, dependency, and vulnerability." Dalam Ethics and Social Welfare. Vol.13, No.2, 100-114.

Friedman, Marilyn. (2000). "Feminism in ethics: Conception of Autonomy." Dalam Miranda Fricker dan Jennifer Hornsby (eds). The Cambridge Companion to Feminist Philosophy. Cambridge: Cambridge University Press.

Gusmian, Islah. (2014). "Filsafat moral Immanuel Kant: Suatu tinjauan paradigmatik." Dalam Al-A 'raf: Jurnal Pemikiran Islam dan Filsafat. Vol IX, No.2, Juli-Desember 2014, 57-66.

Held, Virginia. (1998). "Feminist Reconceptualizations in Ethics." Dalam Philosophy in a Feminist Voice. Disunting oleh Janet A. Kourany. New Jersey: Princeton: University Press, 92-115. 
Held, Virginia . (2010). "Can the ethics of care handle violence?" Dalam Ethics and Social Welfare. Vol.4, No.2, 115-129.

Jena, Yeremias. (2014). "Etika kepedulian: Welas asih dalam tindakan moral." Dalam Kanz Philosophia. Vol.4, No.1, Juni 2014, 1-14.

Koh, Bibiana D. dan Frederic G. Reamer. (2020). "Why moral theories matter: A review of ethics and adoption literature." Dalam Adoption Quarterly. DOI:

10.1080/10926755.2020.1719255.

Magnis-Suseno, Franz. (2000). 12 Tokoh Etika Abad ke-20. Yogyakarta: Kanisius.

Magnis-Suseno, Franz. (2002). "Perkembanganperkembangan Baru dalam Etika." Dalam Diskursus. Vol.1 No.1, April 2002.

Mahmud, Adnan. (2016). "Ajaran moral Immanuel Kant; Jalan menuju kebahagiaan." Dalam Jurnal Tarbiyah Assultaniyah: Jurnal Kajian Sosial, Agama, dan Pendidikan. Vol.8, No.1, 183-203.
Miller, Sarah Clark. (2020). "From vulnerability to precariousness: Examining the moral foundations of care ethics." Dalam International Journal of Philosophical Studies. DOI: 10.1080/09672559.2020.1804239.

Rachels, James. (2004). Filsafat Moral. Diterjemahkan oleh Antonius Sudiarja. Yogyakarta: Kanisius.

Soloviev, Erikh Yu. (2018). "Immanuel Kant: The ethical response to the challenge of the secularization era." Dalam Russian Studies in Philosophy. Vol.56, No.4, 277-295.

Sudarminta, Justinus. (2010). Etika Umum. Jakarta: Pusat Penelitian dan Pengabdian kepada Masyarakat STF Driyarkara. 